\title{
Media Relations 2.0
}

\author{
Mutia Dewi \\ Dosen Program Studi Ilmu Komunikasi \\ Universitas Islam Indonesia, Yogyakarta
}

\begin{abstract}
Delivering media relations activities is a need for organizations to convey public the information they have released. Rapid increase of technology and public's dynamic force Public Relations practitioners to be able to adapt on it. In the era of interactive communication, media relations activities can be done by applying communication technology through internet, therefore it can be performed effectively.
\end{abstract}

Keywords: Public relations, communication technology, media relations, Web 2.o

\begin{abstract}
Abstrak
Melakukan kegiatan hubungan dengan media (media relations) adalah kebutuhan bagi sebuah organisasi untuk meyakinkan publik mengenai informasi yang mereka berikan. Kini, kemajuan teknologi yang amat pesat serta dinamika publik yang tinggi memaksa praktisi Humas untuk bisa beradaptasi dengan kondisi tersebut. Pada era komunikasi interaktif seperti saat ini, aktivitas relasi media bisa dilakukan secara lebih efektif dengan memanfaatkan teknologi komunikasi melalui internet.
\end{abstract}

Kata Kunci: Hubungan masyarakat, teknologi komunikasi, hubungan dengan media, Web 2.o.

\section{Pendahuluan}

Ketika sedang mengalami krisis atau konflik, seringkali sebuah perusahaan atau organisasi mengundang wartawan atau pekerja pers baik cetak maupun elektronik untuk hadir dalam konferensi pers. Ini dilakukan terutama karena adanya kebutuhan untuk memperbaiki citra yang sedang terganggu. Fenomena ini terjadi tatkala organisasi merasa bahwa media memiliki peranan penting bagi kelangsungan hidup organisasi atau perusahaan. Melibatkan media dalam menyebarkan informasi dianggap mampu membantu mengatasi kondisi organisasi yang sedang tidak baik. Karenanya, bagi sebagian organisasi, melibatkan media massa dalam penyampaian informasi kepada masyarakat dianggap sebagai solusi yang paling tepat dalam menyelesaikan masalah secara cepat.

Gambaran di atas menunjukkan bahwa sebagian besar organisasi belum menyadari bahwa bekerja sama dengan media bukanlah sesuatu yang begitu saja terjadi. Butuh waktu, proses, serta kerja sama yang tidak terputus agar keduanya dapat bersinergi dengan baik. Pasalnya, 
bagi media, informasi dari organisasi menjadi sangat penting ketika informasi itu memiliki nilai berita yang tinggi, meskipun belum tentu informasi yang dianggap penting tersebut akan mendatangkan dampak positif bagi organisasi yang bersangkutan. Hal inilah yang kemudian menyebabkan silang kepentingan antara organisasi dan pihak media kerap terjadi, terkait dengan kerja sama yang mereka lakukan.

Selama ini terdapat kekeliruan dalam memahami model kerja sama yang dilakukan dengan media, dan karenanya perlu diluruskan. Menjalin kerja sama dan berhubungan dengan media bukan hanya sekadar barter informasi atau pesan demi sebuah keuntungan dan citra yang baik di hadapan publik. Lebih dari itu, tujuan pokok berhubungan dengan media adalah menciptakan pengetahuan dan pemahaman kepada khalayak sehingga terjadi perubahan konsep berpikir dalam kehidupan masyarakat dan akhirnya terjadi perubahan sikap dan perilaku (Darmastuti, 2012: 45). Apabila ditarik benang merah, maka tujuan akhir dari menjalin hubungan dengan media adalah publik atau khalayak yang memiliki pengaruh bagi suatu organisasi.

$$
\text { Bagi suatu organisasi, }
$$
berhubungan dengan media merupakan suatu keharusan ketika kehidupan segala macam informasi dapat dengan mudah diakses oleh masyarakat melalui media. Jumlah media yang semakin tinggi dan beragam jenisnya membuat masyarakat memiliki pilihan dalam memperoleh informasi. Dengan demikian, perlu pengetahuan bagi organisasi untuk mengenal rekan kerjanya, agar informasi yang sampai kepada masyarakat menjadi seimbang dan tidak merugikan kedua belah pihak. Agar terjaga kerja sama yang baik, organisasi perlu memikirkan divisi yang tepat dan jelas untuk menjalankan kegiatan ini.

Berbicara mengenai menjalin hubungan dengan media tidak terlepas dari ruang lingkup pekerjaan public relations (PR) atau humas dalam sebuah organisasi. Beberapa literatur menyebutkan bahwa hubungan dengan media adalah usaha untuk mencari publikasi atau penyiaran yang maksimum atas suatu pesan atau informasi humas dalam rangka menciptakan pengetahuan dan pemahaman bagi khalayak dari organisasi perusahaan yang bersangkutan (Jefkins, 2004: 113). Hal ini berarti menjalin hubungan dengan media menjadi salah satu pekerjaan penting Divisi Public Relations dalam suatu organisasi. Salah satu tujuan dari pekerjaan public relations adalah membangun citra yang positif dan saling pengertian antara publik dan organisasi, sertamsebagai penghubung informasi dan komunikasi bagi organisasi dengan publik di luar organisasi maupun lingkungan internal organisasi.

Menjalin hubungan dengan media menjadi sangat penting bagi PR karena menurut Public Relations Officer (PRO) 
Universitas Winconsin-River Fall, Barbara Averill, "Media relations hanyalah salah satu bagian dari PR, namun bisa menjadi perangkat yang sangat penting dan efisien. Begitu kita bisa menyusun pesan yang bukan saja diterima, tetapi juga dipandang penting oleh media lokal, maka kita sudah membuat langkah besar menuju keberhasilan program kita” (dalam Iriantara 2005: 28). Mengacu pada pendapat yang disampaikan oleh Averill, begitu luar biasanya hasil yang akan didapatkan oleh organisasi ketika Divisi Public Relations mampu bekerja sama dengan media melalui pesan yang disusun untuk media.

Bekerja sama dengan media tentunya membutuhkan beberapa strategi agar kerja sama tersebut dapat berjalan dengan baik, efektif, dan efisien. Pemilihan media yang tepat dan sesuai dengan publik sasaran menjadi faktor penentu sebagai langkah awal dari kegiatan media relations (Bland, 2005 : 43). Hal ini berkaitan dengan efektivitas informasi yang akan dipublikasikan tepat pada sasaran yang dituju oleh organisasi dan adanya kesesuaian antara organisasi dengan publik yang dituju. Meskipun pemilihan media menjadi faktor penentu bagi seorang PR dalam mempertimbangkan kegiatan media relations-nya, tetapi faktor yang lain seperti jenis media, jangkauan media, serta jumlah audiens juga perlu dipertimbangkan.
Beberapa jenis media yang dapat digunakan dalam kegiatan media relations di antaranya media cetak yang terdiri dari suratkabar dan majalah. Dalam pekerjaan seorang PR, surat kabar memiliki peran yang sangat besar. Melalui surat kabar inilah, seorang PR dapat menyampaikan iklan, berita, maupun advertorial, bahkan melalui surat kabar juga, PR dapat menyampaikan informasi mengenai perkembangan perusahaan atau organisasi. Selain suratkabar, majalah juga dapat digunakan oleh dala aktivitas PR untuk menjangkau segmen-segmen dan komunitas-komunitas khusus, dengan mengangkat topik-topik yang sedang hangat berdasarkan kekhususannya tersebut.

Media elektronik seperti televisi dan radio juga bisa dijadikan sebagai pilihan untuk menjalankan kegiatan media relations. Televisi dengan segala kelebihan dan kepopulerannya dapat menjangkau masyarakat dan dapat memengaruhi masyarakat. Kegiatan yang dapat dilakukan oleh seorang PR di antaranya adalah dengan membuat program acara talkshow, komunikasi interaktif, iklan, siaran pers ataupun yang lainnya. Sementara radio, mempunyai peranan yang sangat besar bagi Divisi Public Relations dalam membangun citra perusahaan. Cara yang dapat dilakukan adalah membuat diskusi interaktif, iklan, siaran pers, bahkan tidak menutup kemungkinan untuk dibuat semacam cerita bersambung dengan tema yang 
berganti mengenai organisasi tempat seorang PR bekerja.

Media lainnya yang dapat dijadikan sarana bagi petugas PR dalam menjalankan kegiatan media relationsnya adalah internet. Internet merupakan media yang berkembang pesat pada saat ini. Perkembangan internet tidak terlepas dari perkembangan teknologi yang mengikutinya. Dengan segala fasilitas yang dimilikinya, internet hadir dengan menawarkan beragam pilihan kepada penggunanya untuk menikmati informasi, hiburan, maupun pendidikan. Selain itu internet juga memberikan fasilitas untuk berkomunikasi bagi penggunanya dengan memanfaatkan dan mengirimkan pesan melalui e-mail, serta membangun hubungan dan jaringan dengan orang lain melalui media sosial. Keberadaan internet dapat digunakan dalam kegiatan PR dalam menyampaikan pesan, informasi, atau apapun yang berhubungan dengan organisasi.

Artikel ini menyoroti bagaimana kegiatan media relations terkait dengan penggunaan internet dan media sosial sebagai salah satu strategi publisitas yang dilakukan oleh PR.

\section{Media dalam Perspektif Teknologi Komunikasi}

Penyebaran informasi melalui
media massa baik cetak maupun
elektronik, mau tidak mau memaksa
masyarakat menjadi konsumen media dan

menjadi masyarakat yang selalu membutuhkan informasi. Terlepas dari fungsi media massa sebagai sarana memperoleh hiburan, pendidikan, maupun informasi, faktanya masyarakat terutama di Indonesia beralih menjadi masyarakat informasi. Masyarakat informasi ini diartikan sebagai masyarakat yang mampu beradaptasi dan mengaplikasikan teknologi terutama dalam distribusi pesan.

Sebenarnya, perkembangan masyarakat dan teknologi berjalan seiringan. Masyarakat yang semakin maju menjadi faktor yang mendukung kemajuan teknologi. Dengan kata lain, perkembangan teknologi sejalan dengan perkembangan masyarakatnya. Hal ini terjadi karena kebutuhan masyarakat yang semakin kompleks, sebagai contoh kebutuhan akan informasi. Menurut Abrar (2003: 15), masyarakat, terutama di kotakota besar, sudah menganggap informasi sebagai komoditas yang berharga ekonomis dan sumber strategis. Kebutuhan akan informasi menjadi salah satu aspek penting yang perlu dipenuhi untuk demi eksistensi kehidupannya.

Pemenuhan akan kebutuhan informasi dapat dilakukan dengan cara apapun. Selain telah diuraikan di atas, banyak media yang bisa dimanfaatkan, peran teknologi menjadi hal yang penting terkait distribusi informasi. Era komunikasi interaktif menjadikan masyarakat kita menjadi masyarakat informasi serta mengubah perilaku dan 
gaya hidup. Sebab, bagi sebagian masyarakat mengaplikasikan teknologi menjadi bagian yang tidak dapat dipisahkan dalam proses mendapatkan informasi. Oleh karena itu dengan masuknya masyarakat dalam era komunikasi interaktif maka proses tukarmenukar pesan pun dapat dilakukan secara verbal maupun gambar dengan menggunakan media interaktif. Media interaktif menjadi media yang digunakan dalam proses bertukar informasi tentunya dengan menggunakan komputer, telepon, ataupun perangkat lainnya.

Era komunikasi interaktif tidak terlepas dari peran internet di dalamnya. Dewasa ini penggunaan internet dari tahun ke tahun terjadi peningkatan. Data yang dirilis oleh Kementerian Komunikasi dan Informasi menyebutkan bahwa pengguna internet di Indonesia menduduki peringkat ketiga di Asia dengan jumlah pengguna sekitar 55 juta orang dari 245 juta penduduk Indonesia. Hal ini wajar terjadi karena internet menjanjikan harapan baru bagi penggunanya. Dengan internet, informasi apapun dapat diakses. Ibaratnya, internet mendekatkan jarak yang terasa begitu jauh.

Pengguna internet yang semakin meningkat, membuat para pekerja media dan pemilik media mulai memanfaatkan jaringan online untuk menembus pasar pembaca dan pemirsanya. Ini bisa dilakukan dengan membuat portal-portal berita online ataupun jaringan media sosial. Media sosial juga menjadi salah satu cara bagi pekerja media untuk melebarkan sayapnya demi meng-update informasi ataupun dijadikan sebagai sarana untuk mendapatkan informasi dari sesama pengguna media sosial. Sebagai contoh, seorang jurnalis mampu mendapatkan informasi penting dari seseorang yang sedang menjadi target berita melalui media sosial yang dimilikinya. Ia dapat menambahkan narasi sendiri kemudian diangkat menjadi sebuah informasi atau berita melalui website medianya.

Terlepas dari positif ataupun negatifnya efek yang terjadi dari perkembangan teknologi komunikasi, peran internet telak memaksa organisasi untuk beradaptasi dengannya. Tentunya dengan didukung dengan perangkat lunak dan keras agar dapat menggunakan internet. Munculnya teknologi komunikasi terbaru juga mengharuskan organisasi mampu beradaptasi dan mengaplikasikannya dalam segala kegiatan organisasi. Organisasi yang juga membutuhkan media dalam aspek kegiatannya tentunya juga harus memahami bagaimana kerja media tersebut dan teknologi apa yang mampu menjangkau audiensnya.

Konsekuensi dari keberadaan teknologi komunikasi memang tidak bisa dilepaskan dari terjadinya perubahan baik dalam sebuah organisasi maupun masyarakat pada umumnya. Tidak heran jika kemunculan teknologi komunikasi 
baru akan menciptakan perilaku informasi baru pula. Baik bagi yang menyampaikan informasi maupun bagi penerima informasi tersebut. Saat ini memang belum semua lembaga atau organisasi yang terkait dengan pelayanan jasa ataupun perdagangan bisa diakses melalui internet. Tetapi tidak mustahil kelak semua lembaga apapun bentuk kegiatannya menggunakan internet dan perangkatnya untuk mencapai customernya.

\section{Cyber Public Relations}

Seperti halnya di banyak negara berkembang, keberadaan PR semakin terasa dibutuhkan oleh organisasi, baik itu organisasi yang bersifat komersial maupun yang nonkomersial. Komposisi Divisi PR antara satu organisasi dengan organisasi lainnya tentunya berbeda sesuai dengan kebutuhan yang dimiliki. Semakin besar dan semakin banyaknya publik yang tersebar dari suatu organisasi tentunya akan membutuhkan kegiatan komunikasi yang berkesinambungan dan terencana agar hubungan dengan publik dapat terjaga. Meskipun demikian, peran PR dalam organisasi apapun, secara umum sama.

Banyak para ahli menyebutkan definisi dari public relations, salah satunya yang disebutkan oleh Jefkins (2004: 10). Ia menyebutkan bahwa public relations merupakan semua bentuk komunikasi yang terencana, baik itu ke dalam maupun ke luar, antara suatu organisasi dengan semua khalayaknya dalam rangka mencapai tujuan-tujuan spesifik yang berlandaskan pada saling pengertian. Definisi tersebut menerangkan bahwa peran seorang PR merupakan bagian yang tidak dapat dipisahkan dari manajemen suatu organisasi. Tidak ada organisasi yang tidak menjalankan kegiatan komunikasinya, karea itu di sinilah peran PR dalam menjalankan kegiatan komunikasi eksternal dan internal organisasi.

Pekerjaan seorang petugas PR yang disebutkan di atas merupakan gambaran sederhana, tetapi lebih dari itu PR dituntut untuk mampu memberikan citra dan publikasi yang baik bagi organisasi serta mampu memberikan manfaat jangka panjang bagi keberlangsungan organisasi. Jadi, tidak perlu menunggu situasi memburuk untuk memulai bekerja, tetapi menginvestasikan hubungan yang baik dengan seluruh stakeholder agar siklus hidup suatu organisasi dapat terjaga dengan baik.

Aktivitas PR tidak terlepas dari membangun hubungan baik. Membangun hubungan baik dengan seluruh stakeholder dapat dilakukan dengan cara apapun sesuai dengan kebutuhan organisasi. Di era teknologi yang semakin maju, diikuti dengan perkembangan internet dan perangkatnya, praktisi PR dituntut untuk dapat beradaptasi, karena publik sebagai tujuan akhir dari PR telah 
mengalami perubahan dan mengaplikasikan teknologi serta perangkat pendukungnya dalam berbagai aspek kehidupann. Akan lebih istimewa lagi jika praktisi PR memiliki pengetahuan dan kemampuan komunikasi dengan individu atau institusi lain tidak saja melalui media massa maupun pers akan tetapi kebutuhan untuk berkomunikasi yang dilakukan melalui internet.

Oleh karena itu, pekerjaan PR dengan menggunakan web akan membuat organisasi semakin mampu menjangkau publik dengan lebih cepat. Perkembangan web 2.0 dari web 1.0 sebelumnya semakin memperlihatkan secara jelas bahwa teknologi akan terus maju seiring dengan keinginan untuk memenuhi kebutuhan manusia. Menurut Graham (2005), web 2.0 merupakan generasi kedua layanan basis web yang memperbolehkan pengguna untuk dapat berinteraksi dan berkolaborasi dengan perangkat lain dalam sebuah media sosial. Sebagai contoh situs jejaring sosial, blog, video chatting, aplikasi web yang menekankan pada kolaborasi online sesama pengguna.

Penggunaan web 2.0 dalam dunia PR cukup signifikan manfaatnya. Salah satu pemanfaatan web 2.0 oleh praktisi PR adalah untuk memenuhi kebutuhan komunikasi baik di lingkungan internal ataupun eksternal. Sebagai contoh pembuatan newsletter, promosi produk baru, ataupun informasi baru, dapat dipublikasikan melalui web yang sudah dibuat baik menggunakan jasa seorang
Programmer ataupun dilakukan oleh praktisi PR itu sendiri. Hal itu tentu saja bertujuan untuk membentuk citra yang positif bagi organisasi.

Kegiatan PR dengan menerapkan aplikasi web ini dapat dilakukan dalam bentuk kegiatan publikasi. Misalnya dengan cara membuat mailing list yang sesuai dengan target golongan masyarakat kemudian secara rutin membuat artikelartikel yang berkaitan dengan organisasi. Dengan begitu setidaknya anggota mailing list setidaknya terkena terpaan dari publikasi yang telah dilakukan.

Aplikasi e-mail dan chatting juga merupakan sebagai salah satu sarana yang bisa dimanfaatkan oleh seorang PR dalam menjalankan kegiatan komunikasinya. Kegiatan ini akan semakin membuat efisensi waktu dan biaya. Karena proses yang cepat serta tidak menggunakan begitu banyak kertas. Melalui aplikasi ini juga, PR dapat berkomunikasi secara interaktif baik dengan publik yang menjadi tujuan organisasi ataupun dengan para pekerja media.

Paparan di atas hanya sebagian dari aplikasi web yang dapat digunakan dalam melaksanakan kerja PR. Pemanfaatan teknologi web ini membutuhkan amatan yang jeli, terkait dengan target publik yang ingin dicapai. Bila sekarang sedang Twitter sebagai media sosial tengah naik daun, mau tidak mau para praktisi PR harus terjun ke dalamnya untuk mengerti seluk beluk dan 
pemanfaatannya. Karena era masyarakat sekarang adalah masyarakat yang bebas berekspresi dan berbicara sesukanya melalui media sosial. Oleh karena itu ketika ada komplain yang disampaikan melalui sosial media, setidaknya PR mampu menanggapinya secara cepat, tanpa harus membiarkan komplain menjadi bumerang bagi organisasi. Salah satu contoh adalah ketika artis Sarah Sechan menyampaikan komplain mengenai bagasi kepada maskapai Garuda Indonesia. Dengan sigap, pihak Public Relations dari Garuda Indonesia menanggapinya.

Oleh karena itu, untuk mengadaptasi perubahan masyarakat dan publik di tengah kemajuan teknologi, praktisi PR harus bersentuhan langsung dengan publik dan konsumen yang ada di dunia maya melalui penggunaan internet. Jadi pandangan konvensional yang masih beranggapan bahwa jurnalis atau pekerja media merupakan satu-satunya partner kerja PR harus diubah. Dengan memahami teknologi ini, maka praktisi PR diharapkan mengerti pula implikasi aplikasi baru tersebut terhadap organisasi ataupun produk yang dihasilkan.

Dengan demikian, secara praktis tugas dan pekerjaan seorang PR tidak lagi sekadar mengelola hubungan dengan media sebagai perpanjangan tangan untuk menyebarkan informasi kepada publik, namun juga dituntut untuk mampu berhubungan langsung dengan publik melalui aplikasi-aplikasi yang disediakan oleh penemuan-penemuan teknologi baru. Hal ini akan berdampak luar biasa kepada organisasi terkait dengan efisiensi biaya dan waktu. Kemudian muncul pertanyaan, apakah dengan kehadiran teknologi ini kegiatan media relations tidak memungkinkan lagi dilakukan oleh praktisi Public Relations?

\section{Media Relations 2.0}

Seperti yang telah disinggung di atas, menjalin hubungan dengan media menjadi kebutuhan bagi suatu organisasi demi tercapainya tujuan organisasi kepada publik. Terlepas dari semua itu, ada beberapa tantangan yang harus dihadapi ketika publik sudah berubah di era web 2.o. Jika sebelumnya para praktisi PR lebih banyak berhubungan dengan media serta mengandalkan media dalam setiap aspek kegiatan, maka perkembangan teknologi menuntut untuk bisa menggunakan dan memfaatkan fasilitas web dalam menjalankan strategi media relations.

Media relations bukanlah satusatunya program yang dapat dijalankan oleh PR untuk menjalankan aktivitas publikasi, tetapi peran media dengan segala kelebihannya juga tidak bisa begitu saja ditinggalkan. Hanya saja, era web 2.0 ini seharusnya dapat dimanfaatkan oleh praktisi PR untuk dapat lebih memudahkan dalam menjalankan pekerjaannya. 
Beberapa langkah atau implementasi dari penerapan web 2.0 yang dapat dilakukan bagi praktisi PR dalam menjalin hubungan dengan media di antaranya sebagai berikut:

\section{E-mail}

Aplikasi ini dapat digunakan untuk mengirimkan siaran pers, tentunya PR sudah menyimpan database alamat e-mail para wartawan. Aplikasi ini tidak saja digunakan pada saat kita membutuhkan wartawan untuk keperluan siaran pers tetapi dijadikan sebagai salah satu cara PR untuk mengelola relasi. Bisa dilakukan dengan cara selalu berkomunikasi dengan baik atau sekadar menyapa wartawan dan mengabarkan rencana kegiatan yang dilakukan. Mengelola relasi melalui e-mail tidak saja hanya melibatkan pekerjanya saja, institusi medianya pun tidak dapat diabaikan begitu saja.

\section{Chatting}

Aplikasi ini dapat digunakan oleh praktisi PR untuk melayani wawancara dengan insan pers atau konferensi pers, melalui berbagai aplikasi yang ada. Hal ini mungkin dilakukan dengan mempertimbangkan efisiensi waktu dan kecepatan naiknya berita yang akan diinformasikan kepada publik. Ini lebih efektif dibandingkan jika PR harus menyediakan tempat untuk melakukan kegiatan media relations kemudian harus menunggu wartawan berkumpul. Tentu akan menguras cukup banyak waktu dan tenaga. Maka dengan adanya aplikasi chatting, pertemuan yang tadinya akan memakan waktu lama dapat dilakukan dengan cepat.

3. Akun jejaring sosial

Akun jejaring sosial dapat digunakan oleh praktisi PR untuk menyebarluaskan aneka informasi atau berita yang berhubungan dengan organisasinya, kemudian artikel tersebut diposting ke media online. Jika diperlukan, bisa dilanjutkan dalam bentuk konferensi pers. Kegiatan seperti ini biasanya dilakukan ketika organisasi mengalami situasi krisis yang membutuhkan penangan cepat dan penyebaran informasi secara cepat. Perlu diketahui, tidak hanya satu organisasi saja yang menjadi fokus pekerja media, karena itu praktisi PR harus sigap dan jeli melihat peluang untuk menjadi penting di mata media. Dengan demikian, berita yang berkembang di masyarakat mampu dikontrol oleh PR.

4. Fasilitas web

Fasilitas berikutnya yang disediakan melalui jaringan internet adalah website. Website 
merupakan media komunikasi online yang dapat memuat beragam informasi untuk diketahui khalayak umum mengenai organisasi. Website ini dapat digunakan sebagai akses informasi bagi para pekerja media untuk mengetahui lebih jauh mengenai organisasi. Bagi PR, website digunakan untuk mencantumkan segala hal yang berkaitan dengan organisasi dan tidak lupa menyertakan kontak yang bisa dihubungi oleh publik ataupun media. Isi dari website ini tentulah harus dibuat seatraktif mungkin agar menarik publik untuk mengunjungi website.

5. Youtube

Situs yang satu ini merupakan saluran informasi yang dapat digunakan oleh praktisi PR untuk menggunggah informasi berupa video terkait dengan organisasinya. Harapannya, video ini menarik pekerja media kemudian meneruskan publikasi di medianya. Penggunaan Youtube pernah dipraktikkan oleh Pemerintah Provinsi DKI yang mengunggah video kegiatan rapat wakil Gubernur DKI Basuki. Sepintas memang terlihat sederhana, tetapi berdampak luar biasa, dibuktikan dengan banyaknya orang yang menonton video tersebut. Insan pers dapat memanfaatkan informasi ini dengan cara menjadikannya sebagai headline dalam program berita. Hal ini secara tidak langsung memberikan citra yang positif pada Pemprov DKI.

6. Blog

Merupakan media komunikasi efektif yang dapat digunakan dan dimanfaatkan oleh praktisi PR maupun pekerja media. Salah satu manfaat yang dapat dirasakan dengan memanfaatkan blog adalah dengan memposting berbagai artikel yang terkait dengan organisasi dan blog juga dapat dijadikan sebagai sarana berkomunikasi baik dengan insan pers ataupun dengan publik yang berhubungan dengan organisasi.

Paparan di atas merupakan sekelumit kegiatan media relations yang dapat dilakukan dengan memanfaatkan teknologi di dalamnya. Implementasi lainnya dapat dilakukan organisasi sesuai dengan kebutuhan dan penerapan tekonologinya. Pada intinya, era komunikasi interaktif menuntut praktisi PR untuk dapat menyesuaikan diri dengan segala dinamika yang terjadi baik di lingkungan masyarakat maupun partner kerjanya.

Melalui penerapan Media Relations 2.o, organisasi akan merasakan banyak manfaatnya. Pertama, respon dari publik terkait dengan organisasi akan 
dirasakan semakin cepat karena bantuan teknologi internet. Kedua, ketergantungan terhadap media tidak lagi terjadi dalam menjalankan kegiatan media relations, sebab aplikasi teknologi dapat memudahkan pekerjaan PR. Ketiga, efisiensi biaya dan waktu. Kegiatan media relations yang dilakukan dengan memanfaatkan teknologi seperti yang telah dipaparkan di atas akan meringankan biaya yang dikeluarkan jika dibandingkan dengan melaksanakan kegiatan media relations secara konvensional.

Penerapan model kegiatan media relations dengan mengaplikasikan teknologi di dalamnya, tidak melupakan unsur-unsur penting serta tujuan akhir dari kegiatan ini. Aplikasi yang ada hanya sebagai penunjang kerja dari praktisi Public Relation, namun yang paling penting adalah bagaimana seorang PR menyadari bahwa masyarakat selalu mengalami perubahan. Untuk mencapai masyarakat sebagai sasaran, PR harus mampu menyesuaikan diri dengan perubahan itu, agar tetap bisa mencapai publiknya. Kegiatan-kegiatan yang dilakukan tidak lagi sebatas mengelola hubungan dengan rekan kerja dalam hal ini media, tetapi mampu menembus langsung publik sebagai tujuan dari organisasi.

\section{Penutup}

Menjalin hubungan dengan media adalah salah satu agenda penting dalam kegiatan praktisi PR. Media dianggap sebagai partner kerja yang penting untuk menjadi perantara dalam menyampaikan informasi. Tetapi, dengan perkembangan masyarakat dan teknologi, kegiatan berhubungan dengan media tidak lagi dilakukan dengan cara konvensional seperti menyebarkan undangan, mengumpulkan wartawan untuk konferensi pers, ataupun dengan cara mengundang media untuk datang meliput kegiatan organisasi. Hal ini dapat dilakukan pula dengan mengimplementasikan teknologi dalam bentuk chatting, pemanfaatan e-mail, Facebook, Twitter, Youtube, dan sebagainya.

Meskipun kegiatan konvensional masih sah untuk dilakukan, akan tetapi ada beberapa metode lainnya yang memungkinkan aplikasi teknologi terlibat di dalamnya. Hal ini terkait dengan perkembangan masyarakat dan dinamika perkembangan industri media massa. Yang perlu dicatat bagi insan media atau pekerja media adalah bagaimana memposisikan organisasinya menjadi penting di mata media yang semakin dinamis serta di mata masyarakat yang menjadi tujuan dari sebuah organisasi. 


\section{Daftar Pustaka}

Abrar, Ana Nadhya. 2003. Teknologi Komunikasi: Perspektif Ilmu Komunikasi. Yogyakarta: LESFI.

Bland, Michael, David Wragg, Alison Theaker. 2005. Effective Media Relations: How To Get Results. London: Kogan Page.

Darmastuti, Rini. 2012. Media Relations: Konsep, Strategi \& Aplikasi. Yogyakarta: Andi Offset.
Graham, Paul. 2005. "Web 2.0", dalam http://www.paulgraham.com/we b2o.html, diakses 12 Februari 2012.

Iriantara, Yosal. 2005. Media Relations: Konsep, Pendekatan dan Praktik. Bandung: Simbiosa Rekatama Media.

Jefkins, Frank. 2004. Public Relations. Jakarta: Erlangga. 